\title{
Success of constructed oyster reefs in no-harvest sanctuaries: implications for restoration
}

\author{
Sean P. Powers ${ }^{1, *}$, Charles H. Peterson ${ }^{2}$, Jonathan H. Grabowski ${ }^{3}$, Hunter S. Lenihan ${ }^{4}$ \\ ${ }^{1}$ Department of Marine Sciences, University of South Alabama and Dauphin Island Sea Lab, 101 Bienville Blvd., \\ Dauphin Island, Alabama 36528, USA \\ ${ }^{2}$ Institute of Marine Sciences, University of North Carolina at Chapel Hill, 3431 Arendell Street, Morehead City, \\ North Carolina 28557, USA \\ ${ }^{3}$ Gulf of Maine Research Institute, 350 Commercial Street, Portland, Maine 04101, USA \\ ${ }^{4}$ Donald Bren School of Environmental Science \& Management, Bren Hall 3428, University of California, Santa Barbara, \\ California 93106, USA
}

\begin{abstract}
Dramatic declines in populations of the eastern oyster Crassostrea virginica are a symptom of degradation in many US Atlantic and Gulf of Mexico estuaries. We sampled 94 oyster reefs (88 constructed, 6 natural) within 11 no-harvest sanctuaries in estuaries of central and northern North Carolina, USA, to evaluate the success of oyster sanctuaries as a conservation tool. The sanctuaries have been in existence from 3 to $30 \mathrm{yr} 10$ sanctuaries protect constructed ('restored') oyster reefs and 1 sanctuary protects natural reefs. Measurements of vertical relief, live oyster density, recruitment, abundance of market-sized oysters, and biomass as well as disease prevalence and severity indicated that 7 of the 11 sanctuaries met criteria for minimal success by having vertical relief $>20 \mathrm{~cm}$ in height, living oysters (>10 oysters $\mathrm{m}^{-2}$ ), and evidence of recent recruitment in 1 of $2 \mathrm{yr}$ of the survey. Most reefs within the 7 sanctuaries far surpassed these relatively low benchmarks. For reefs that failed, burial by sedimentation appeared to be the primary cause in 2 sanctuaries, poor water quality (low dissolved oxygen) in 1, and poor oyster recruitment in another. All intertidal reefs were successful and had significantly higher densities of all size categories of live oysters (spat, adult, marketable size) than subtidal oyster reefs. Disease prevalence and severity were low in sanctuary reefs despite high oyster densities and increased longevity of oysters on these reefs. Pronouncements that restoration of the native eastern oyster is a failure prove incorrect when a decade-long history of oyster reef sanctuaries is evaluated. The proposed introduction of a non-native oyster into the US Atlantic coast estuaries cannot be justified by claiming failure of native oyster restoration in light of promising successes within sanctuaries.
\end{abstract}

KEY WORDS: Crassostrea virginica $\cdot$ Marine protected areas $\cdot$ No-harvest sanctuaries $\cdot$ Oyster disease $\cdot$ Restoration $\cdot$ Fisheries

Resale or republication not permitted without written consent of the publisher

\section{INTRODUCTION}

The century-long and accelerating decline of the eastern oyster Crassostrea virginica in estuaries along the Atlantic and Gulf of Mexico coastlines of North America has been widely publicized (Hargis \& Haven 1988, Rothschild et al. 1994, Coen \& Luckenbach 2000), but until recently, this dramatic anthropogenic change (Kirby 2004) has been considered little more than a local fisheries issue. The failure to sustain oyster fisheries with the attendant economic and social costs is indeed a significant consequence of the oyster population crash. However, a century of considering eastern oysters narrowly as an exploitable fishery resource and placing responsibility for their management in the hands of fisheries management agencies (Coen \& Luckenbach 2000, Luckenbach et al. 2005) has led to decisions about harvest controls, restoration, and intro- 
ductions of non-native substitutes that have not been made in a holistic context and have consequently contributed to a widespread estuarine conservation crisis (Jackson et al. 2001).

Oysters provide substantial ecosystem services that have only recently been documented and appreciated (Lenihan \& Peterson 1998, Coen et al. 1999, 2007, Lenihan et al. 2001, Grabowski et al. 2005). The eastern oyster forms an emergent reef that functions like other recognized biogenic habitats to provide important ecosystem services. Unlike coral reefs, seagrass meadows, salt marshes, and mangrove forests, oyster reefs are permitted by state management agencies to be mined and degraded to extract the marketable oysters from the reef formation (DeAlteris 1988, Hargis \& Haven 1988, Rothschild et al. 1994, Lenihan \& Peterson 1998). Oyster reef habitat enhances estuarine biodiversity (Wells 1961, Luckenbach et al. 2005) by providing the only extensive emergent hard substratum for epibiotic invertebrates. Areal production of fish and invertebrates is increased by oyster reef habitat to a far greater degree than by salt marsh habitat (Peterson et al. 2003 as compared to Kneib 2003), whose strict regulatory protection in the US and elsewhere is largely based upon its high productivity. As a suspensionfeeding bivalve, oysters may improve estuarine water quality by removing sediments and microalgae (Dame et al. 1984, Nelson et al. 2004, but see Pomeroy et al. 2006) and by stimulating denitrification (Newell et al. 2002).

Proper recognition of the value of these and other ecosystem services of oysters would imply more holistic ecosystem-based management of oysters and the reefs they build (Burreson et al. 2000, Mann 2000). A commitment to ecosystem-based management of oysters should address issues such as the optimal design of restored oyster reefs (Lenihan \& Peterson 1998, Posey et al. 1999), non-destructive harvest techniques (Lenihan \& Peterson 2004), establishment of networks of oyster reef sanctuaries so as to provide refuges from stresses for mobile fishes (Breitburg et al. 2000, Lenihan et al. 2001) and facilitate larval retention to sustain recruitment (Mann 2000, Lipcius et al. 2008), development and adoption of metrics to evaluate the success of restoring oyster reefs (O'Beirn et al. 1999, Coen \& Luckenbach 2000, Luckenbach et al. 2005), and the consequences of non-native oysters as replacements for declining native oysters (NRC 2003). The responses to these challenges are likely to differ if based on ecosystem services as opposed to fishery production alone. After substantial efforts to restore eastern oysters in Chesapeake Bay, local fisheries managers and some scientists have been pronouncing oyster restoration a failure (Mann \& Powell 2007). In response, some organizations have been advocating intentional intro- duction of a non-native oyster from China into Chesapeake Bay (see NRC 2003 for details) despite the known environmental risks of species introductions (Carlton 1989, Naylor et al. 2001).

Here, we examined the fate of 94 oyster reefs protected for 3 to $30 \mathrm{yr}$ within 11 sanctuaries located in the North Carolina Outer Banks. Specifically, we quantified density, biomass, and recruitment of oysters over 2 successive years, and prevalence and severity of oyster disease as indications of success of restoration. Oyster disease is considered by many to be the primary inhibitor of eastern oyster recovery, motivating our disease assessment. Finally, we identified the physical site characteristics that were associated with successful oyster reef restoration.

\section{MATERIALS AND METHODS}

Study design. We surveyed oyster reefs within 11 sanctuaries from May 2002 to September 2003. Beginning at the southern end of the study area (Fig. 1), 1 sanctuary was located in Bogue Sound, 3 within Back Sound (Bird Shoals, Middle Marsh I and II), 3 within the Neuse River Estuary (Neuse River shallow, middepth, and deep), 3 in Pamlico Sound (West Bay, Deep Bay, and Crab Hole), and 1 in Croatan Sound (Wanchese). Ten of these sanctuaries were created to prevent damage from bottom-disturbing fishing practices on reefs built by state and federal agencies or university scientists. One sanctuary, Bird Shoals, included only natural reefs protected for at least the last 30 yr by continuous closure based on water-quality concerns arising from proximity to a municipal wastewater discharge. The constructed oyster reefs varied in age, with the oldest constructed in 1992 and the most recent in 2000 (Table 1). The reefs also varied in overall dimensions, height, and configuration: 6 were composed of a network of small to mediumsized (5 to $35 \mathrm{~m}^{2}$ ) oyster reefs (Bird Shoals, Middle Marsh I and II, Neuse River shallow, mid-depth, and deep), and 5 were continuous reefs with variable dimensions (Bogue, West Bay, Deep Bay, Crab Hole, Wanchese). Of the 11 sanctuaries, 8 were protected subtidal reefs (3 to $6 \mathrm{~m}$ depths) and 3 were intertidal reefs (Bird Shoals, Middle Marsh I and II). Most sanctuary areas were in relatively high-salinity waters $(22$ to $32 \mathrm{psu}$ ), the exceptions being reefs in the Neuse River, Deep Bay, and Wanchese, which were primarily mesohaline (10 to 20 psu; see hydrographic data in Lenihan \& Peterson 1998). Oyster reefs in the Neuse River, particularly those in deeper waters, may experience periods (days to weeks) of hypoxia, defined as dissolved oxygen concentrations $<2.0 \mathrm{mg} \mathrm{l}^{-1}$ (Lenihan \& Peterson 1998, Powers et al. 2005). 


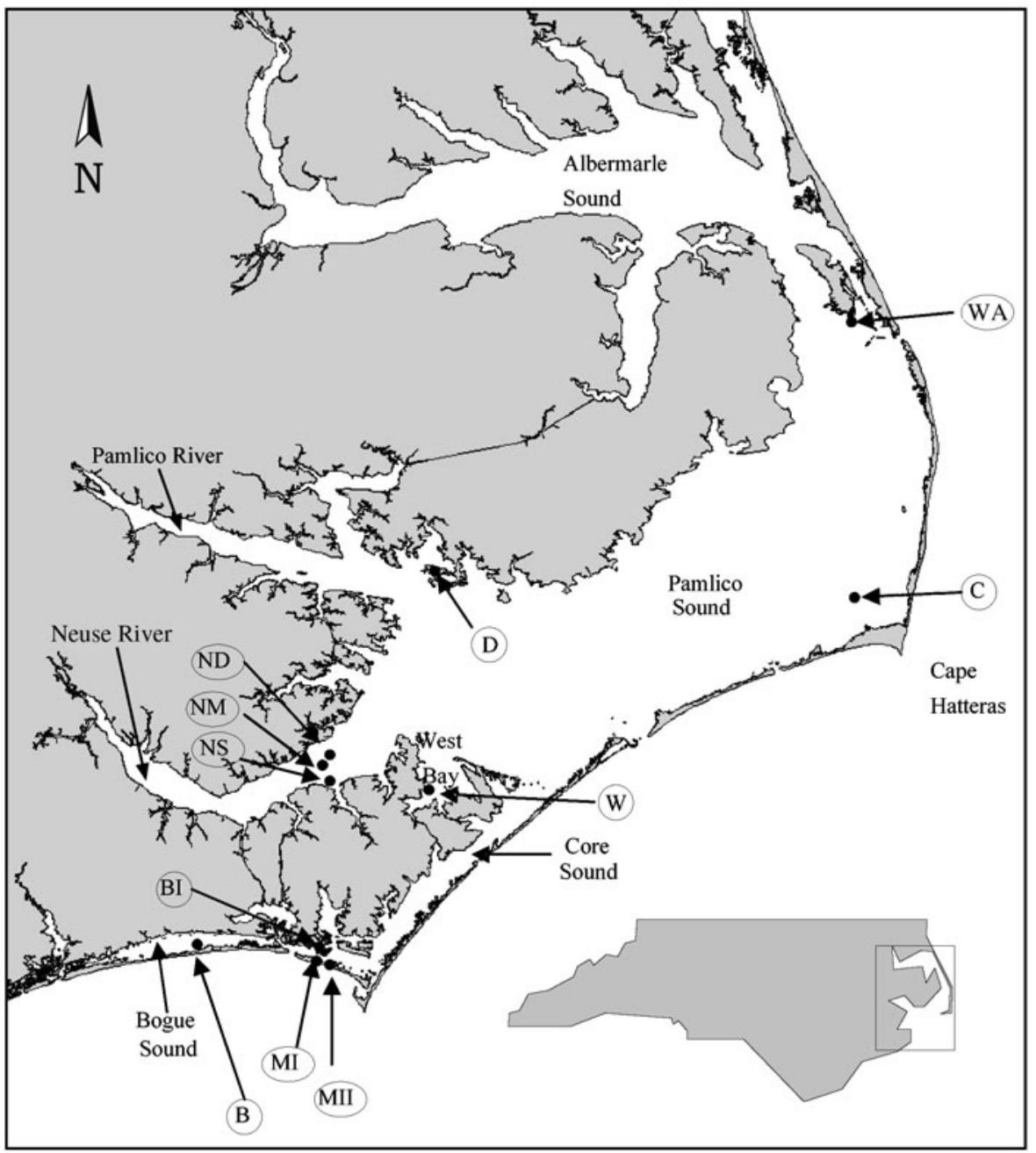

Fig. 1. Outer Banks region of North Carolina. Sanctuary areas (circles) from south to north are Bogue Sound (B), Bird Shoals (BI), Middle Marsh I and II (MI, MII), Neuse River shallow (NS), mid-depth (NM), and deep (ND), West Bay (W), Crab Hole (C), Deep River (D), and Wanchese (WA)

Because many of the sanctuaries had not been recently surveyed and had no recorded GPS coordinates, visual inspections of oyster reefs within all sanctuary areas were conducted in May or June 2002 prior to quantitative sampling. For subtidal reefs, these inspections were performed by SCUBA divers and for intertidal reefs via shoreline surveys. After the initial surveys, 3 of the sanctuary reefs were sufficiently characterized that they needed no follow-up quantitative sampling: the Bogue Sound and the Neuse River middepth sanctuaries were completely buried by sand, and the Crab Hole sanctuary had no live oysters. Quantitative sampling for oyster density within the remaining sanctuary areas was conducted in September 2002 and 2003; disease assessment was performed in both June and September of 2002 and 2003.

Quantitative sampling and parameter contrasts. To estimate densities of live oysters, quadrat samples $\left(0.25 \mathrm{~m}^{2}\right)$ were collected by hand, either SCUBA diving (subtidal reefs) or kneeling (intertidal reefs), from the base and crest of each oyster reef. All oyster and shell material to a depth of $15 \mathrm{~cm}$ within the quadrat frame was excavated, placed in mesh sacks, and returned to the University of North Carolina's Institute of Marine Sciences. Samples were temporarily stored in outdoor, flow-through-seawater tanks until analysis was completed (usually 12 to $48 \mathrm{~h}$ after collection). All oysters larger than $25 \mathrm{~mm}$ in shell height $(\mathrm{SH}=$ distance from umbo to anterior shell margin) and spat (newly recruited oysters $\leq 25 \mathrm{~mm} \mathrm{SH}$ ) were separately enumerated, and a subsample of 20 larger oysters was individually measured. Based on these size measurements, we placed oysters $>25 \mathrm{~mm}$ in $\mathrm{SH}$ into 2 size categories: all oysters $>25 \mathrm{~mm}$ ('oysters') and oysters $\geq 75$ mm ('market-sized oysters'). After enumeration and measurement, the total wet weight of live oysters and 


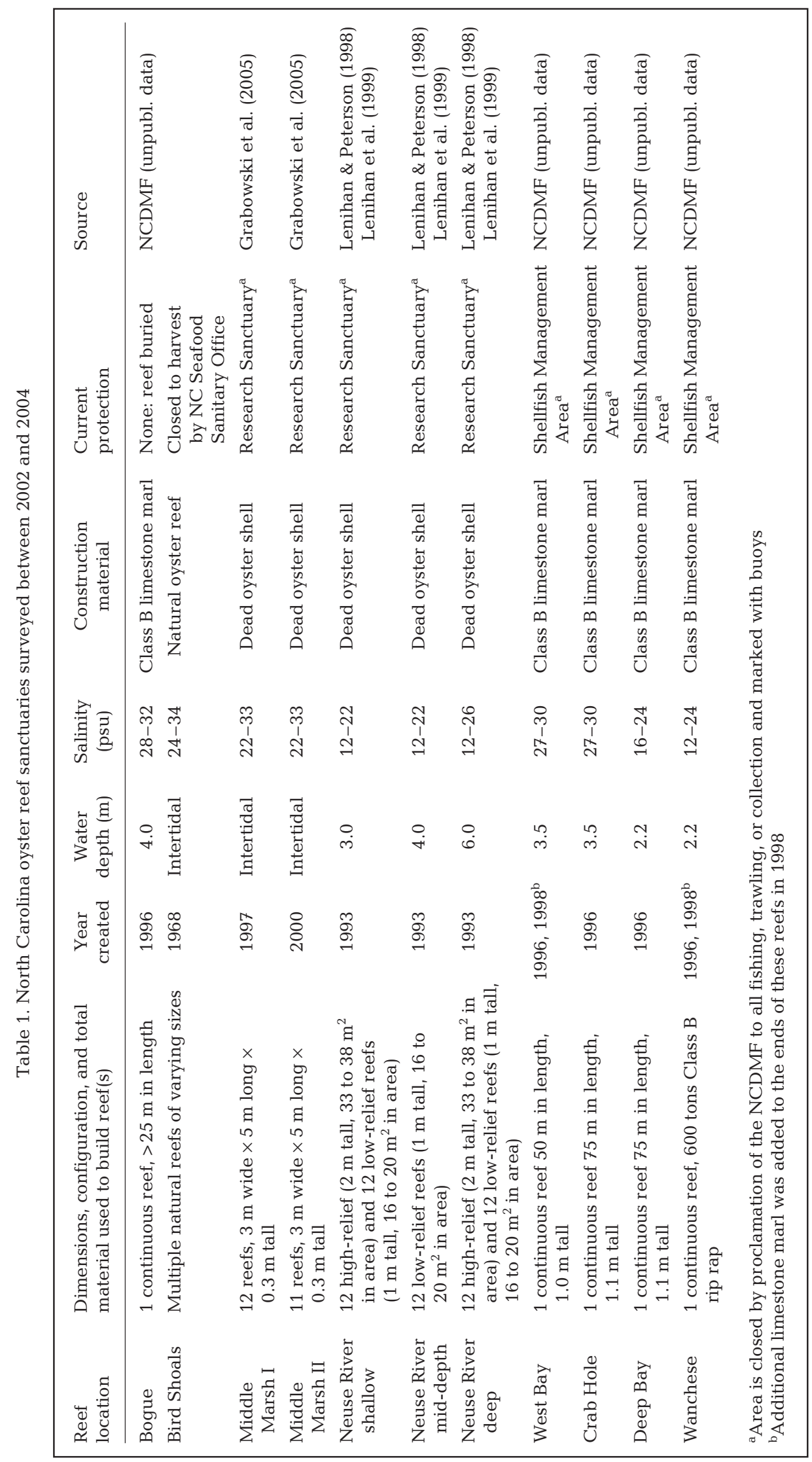


spat was measured for each quadrat. We refer to this measurement as 'oyster biomass,' because both the shell and soft tissue are biogenic.

For the Bird Shoals and the Neuse River shallow and deep sanctuaries, which consisted of multiple reefs, replicate quadrat samples were collected haphazardly from the base and crest of 6 randomly selected reefs. Because the Middle Marsh I and II sanctuaries were intertidal and easily accessible, all reefs were sampled from those areas. For the West Bay, Deep Bay, and Wanchese sanctuaries, which consisted of a single large reef per sanctuary, quadrat samples were collected at the base and crest from 3 widely spaced locations: 1 sample at each end and 1 in the center of the reef. The resulting separation between samples of $\sim 20 \mathrm{~m}$ was equivalent to distances between many of the replicate reefs in other sanctuaries.

We defined the success of oyster reef restoration based on 3 metrics that focus on sustainability of oysters: presence of vertical structure above the bottom, presence of live oysters, and evidence of recruitment. Settlement and growth of oysters is the key function of an oyster reef with additional benefits stemming from it. We considered an oyster reef to meet 'minimum' success criteria if (1) oyster density was $>10 \mathrm{~m}^{-2}$ (at least 2 oysters $>25 \mathrm{~mm} \mathrm{SH}$ per $0.25 \mathrm{~m}^{2}$ quadrat), (2) the emergent reef structure was at least $20 \mathrm{~cm}$ above the bottom, and (3) there was evidence of spat recruitment in at least 1 of the 2 survey years. These minimum criteria would indicate some temporal sustainability. Ideally, we would use data from natural reefs to gauge the trajectory of success; however, finding such reefs throughout the large expanse of estuary was not logistically feasible. Alternative metrics for determining success that reflect ecosystem benefits (e.g. fish utilization, filtration ability, benthic infaunal and epifaunal densities) have been proposed and used by many investigators. However, assessment of many of these metrics would be far too labor intensive over 94 reefs. We acknowledge that our success criteria are low, but in practice, our successful reefs had much higher levels of oyster density and recruitment, whereas reefs that failed these minimum criteria were clearly not persistent. After assessing minimal success, we used increases in oyster densities and biomass as indicators of ecological benefit (see Luckenbach et al. 2005) and mounting densities of market-sized oysters as an indicator of oyster fishery benefit.

Disease analysis. The protozoan endoparasite Perkinsus marinus, commonly referred to as 'dermo', is transmitted by infective waterborne cells released in the pseudofeces of infected oysters or when infected oysters gape and the deteriorating flesh releases the parasite (Andrews 1988, Soniat 1996). Infection begins in the digestive tract, and parasitic cells spread throughout the body, where they cause lysis of oyster cells, particularly in connective tissue, adductor muscle, digestive epithelium, and blood vessels. Tissues become composed primarily of dermo cells, and oysters appear to die from failure of major organ systems (Andrews 1988). Dermorelated mortality is highest in oysters during the second and third yr of life, when oysters typically reach 60 to $85 \mathrm{~mm}$ in SH (Andrews \& Ray 1989). Prior to death, sublethal effects include reduced growth and fecundity, and discolored meat (Andrews 1988, Paynter \& Burreson 1991). Dermo infections are normally assessed by sampling tissue from individual oysters and, after a special culture technique, counting the infective cells.

Following the same temporal and spatial design as the quadrat sampling, 20 to 30 live oysters (65 to $95 \mathrm{~mm} \mathrm{SH}$ ) were collected annually from the base and crest of each sanctuary reef. Infection level of Perkinsus marinus for each oyster was determined by removing a 3 to $5 \mathrm{~mm}$ long section of the rectum of each oyster and analyzing for the presence of $P$. marinus using the thioglycolate staining method (Ray 1963, Paynter \& Burreson 1991). Each rectum sample was stained with thioglycolate solution, mounted on a microscope slide after a $5 \mathrm{~d}$ incubation period, and the number of $P$. marinus hypnospores counted in each of 3 haphazardly selected visual fields using a Wild M20 compound microscope at $100 \times$. The mean number of hypnospores was then determined for each oyster from counts in the 3 visual fields. Prevalence of infection was calculated as the proportion of oysters infected in each group of 20 to 30 oysters collected. A weighted intensity of infection was calculated using Mackin's scale (Quick \& Mackin 1971) in which the concentration of parasite cells from each infected oyster is assigned a score of 0 , 1, 3, or 5. Oysters with 10 to 100 P. marinus cells per field of a microscope slide are considered lightly infected (score $=1$ ), 100 to 1000 cells mildly infected $($ score $=3)$, and $>1000$ cells heavily infected (score $=5$ ). Weighted intensity of infection for each replicate group of 20 to 30 oysters was then computed.

Statistical analysis. Univariate analyses tested for differences in density of each of 3 size classes of oysters ( $\leq 25 \mathrm{~mm} \mathrm{SH}$ [recruitment of spat], $>25 \mathrm{~mm} \mathrm{SH}$, and $>75$ $\mathrm{mm} \mathrm{SH}$ [market-sized]), oyster biomass, and disease prevalence among sanctuary reefs. Prior to all analyses, data were tested for normality (Kolmogorov-Smirnov test) and homogeneity of variances (Cochran's test) at $\alpha$ $=0.05$ : in only 1 case, spat recruitment, was transformation $(\sqrt{ } x+0.5)$ necessary. Two-way analysis of variance (ANOVA) tested for differences in densities of each size class of oyster and oyster biomass among 8 sanctuaries (Bird Shoals, Middle Marsh I, Middle Marsh II, Neuse River deep, Neuse River shallow, West Bay, Deep Bay, and Wanchese) and sampling year (September 2002 and September 2003). The oyster response variables 
used in these analyses came from samples on the crest of the reef, which was normally higher than at the base and less variable. For all ANOVAs, each reef within sanctuary areas containing multiple reefs was used as a separate replicate, whereas each of the 3 locations was used as replicates for those sanctuaries composed of 1 large reef. Student-Newman-Keuls (SNK) post hoc comparisons were performed on all significant main effects from the ANOVAs.

We also performed 2-tailed, paired $t$-tests on transformed spat recruitment and untransformed oyster density, market-sized oyster density, oyster biomass, average $\mathrm{SH}$ of oysters, disease prevalence and disease severity to test the effects of position on the reef (base versus crest). Each base mean was paired with its corresponding crest measurement for September 2002 and 2003. Although a June data set for disease prevalence and severity was also collected, disease levels are highly correlated between early and late summer with infection levels generally increasing over the summer, allowing higher resolution of differences in September.

\section{RESULTS}

\section{Reef surveys}

For 9 of the 11 sanctuary areas, emergent reef structure was still evident in 2002. The exceptions were the Neuse River mid-depth and Bogue Sound sanctuaries, which appeared to have been buried by sand. The Bogue Sound sanctuary, located in a sandy-bottom, relatively energetic flow regime, had become covered by sand within 1 yr of construction (North Carolina Division of Marine Fisheries [NCDMF] unpubl. data). The Neuse River mid-depth sanctuary consisted of 12 oyster reefs (1.0 m tall) constructed in 1992. Through dive searches using poles, we located 4 of the 12 reefs buried under a $0.3 \mathrm{~m}$ layer of coarse sand. The remaining 8 reefs were also assumed to be buried after finding no above-bottom or subsurface structure after $2 \mathrm{~h}$ of searching.

Of the 9 remaining sanctuaries, 1 had no (Crab Hole) and 1 very few (Neuse River deep) adult live oysters $>25 \mathrm{~mm} \mathrm{SH}$. The limestone marl and concrete materials used to create reef structure for the Crab Hole sanctuary appeared completely overgrown by tunicates, bryozoans, barnacles, and small mussels. Divers observed no live oysters or spat recruitment at this sanctuary in 2002. Of 12 high-relief $(2.0 \mathrm{~m}$ tall $)$ and 12 low-relief $(1.0 \mathrm{~m}$ tall) reefs created at the Neuse River deep sanctuary, 9 high and 6 low reefs were located during a total of $4 \mathrm{~h}$ of diver search time and $4 \mathrm{~h}$ of surface-vessel search using a depth profiler. The physical structure of all 9 high and 6 low reefs in the Neuse
River deep sanctuary was completely intact, with vertical relief on high reefs ranging from 1.5 to $1.9 \mathrm{~m}$ and on low from 0.7 to $0.9 \mathrm{~m}$.

Among the 8 sanctuaries characterized by physical structure above the sediment surface and live oysters, those constructed in intertidal areas and those made of bivalve shells in subtidal areas succeeded in sustaining complex 3-dimensional habitat. Of the 12 intertidal reefs created in 1997 and 11 intertidal reefs created in 2000 for the Middle Marsh I and II sanctuaries, all were intact with 50 to $100 \%$ coverage of live oysters. Diver observations of subtidal oyster reefs within sanctuaries, as well as visual inspection of quadrat samples, suggested that reefs created with limestone marl had less structural complexity than subtidal reefs created with bivalve shell material. Reefs at the West Bay, Deep Bay, and Wanchese sanctuaries, made of 8 to $12 \mathrm{~cm}$ diameter pieces of limestone marl, tended to harbor only scattered single oysters attached to the marl. In contrast, oysters formed large clumps of 4 to 8 individuals on the Neuse River shallow reefs, the only subtidal sanctuary reef created with bivalve (oyster) shell material. Oyster clumps were also common in harvest areas created via deposition of bivalve shell material in locations near the West Bay and Deep Bay sanctuaries. Of the 24 reefs created at the Neuse River shallow sanctuary, 14 appeared intact with live oysters present. Vertical relief of the 14 reefs ranged from 0.5 to $1.1 \mathrm{~m}$, which along with absence of initial GPS information inhibited us from establishing which reefs were originally constructed as high $(2 \mathrm{~m})$ or low $(1 \mathrm{~m})$ relief. In addition, a large quantity of shell material, some colonized by live oysters, was scattered throughout the sanctuary area, suggestive of remnants of reefs destroyed by illegal harvest or storms.

\section{Oyster metrics within sanctuaries}

There was a significant effect of sanctuary $\left(F_{7,81}=\right.$ $3.65, \mathrm{p}=0.002)$ and no effect of collection period $\left(F_{1,81}\right.$ $=1.41, \mathrm{p}=0.232)$ or the interaction $\left(F_{7,81}=0.58, \mathrm{p}=\right.$ 0.768 ) on oyster spat density. Spat density averaged over the 2 yr was higher in the 3 intertidal sanctuaries (Bird Shoals, Middle Marsh I and II) than in all other sanctuaries, although only the Middle Marsh sanctuaries differed significantly from the subtidal sanctuaries (SNK post hoc contrasts, $\alpha<0.05$ ). Successful spat recruitment was evident on all intertidal reefs within each sanctuary area in both years. The 5 subtidal sanctuaries did not differ in spat density (Fig. 2). Lowest spat recruitment occurred on the Wanchese reef, with 4 spat $\mathrm{m}^{-2}$ in 2002 and no recruitment in 2003. Successful spat recruitment was evident on reefs within other subtidal sanctuaries surveyed in both 2002 and 2003. 

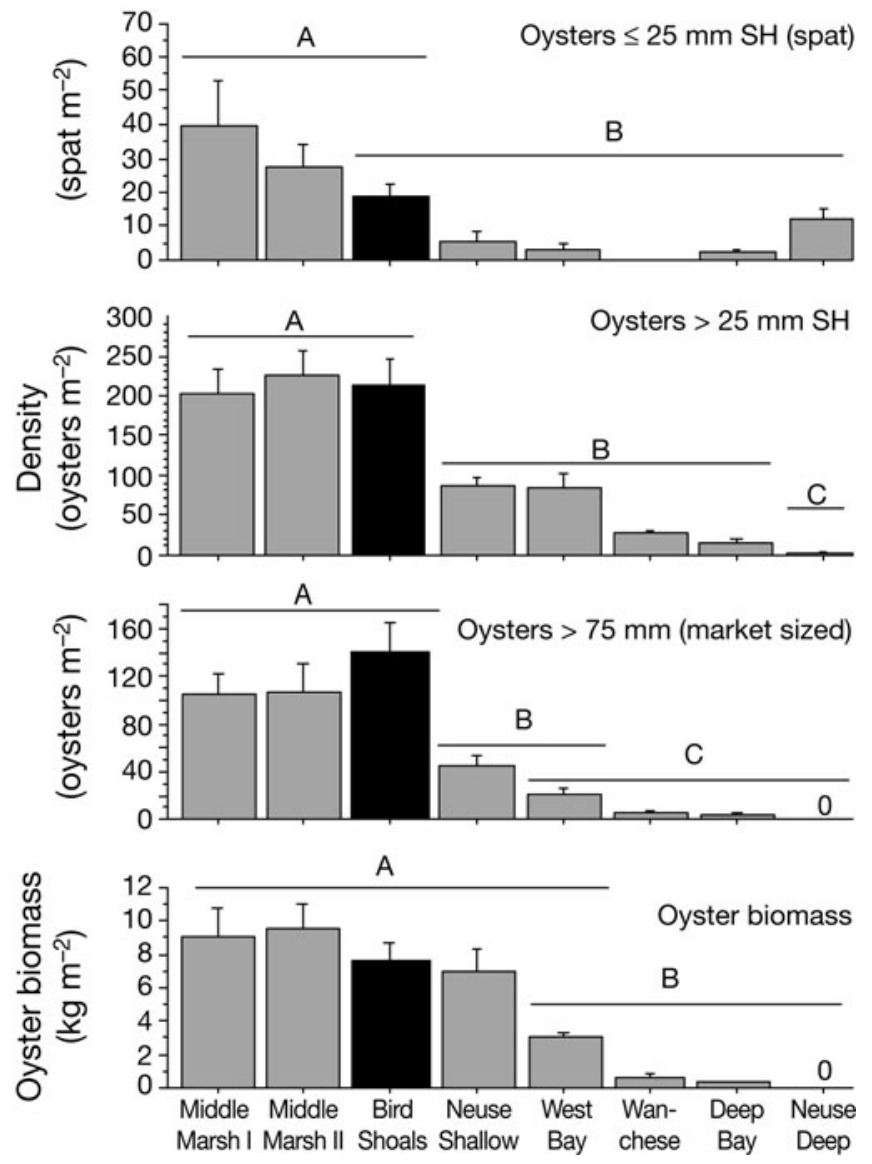

Fig. 2. Mean (+ $1 \mathrm{SE})$ density of oysters in 3 size categories, $\leq 25 \mathrm{~mm}$ shell height ( $\mathrm{SH}_{i}$ spat), $>25 \mathrm{~mm} \mathrm{SH}$ (oysters), > $75 \mathrm{~mm}$ $\mathrm{SH}$ (market-sized), and biomass $\mathrm{m}^{-2}$ (shell + soft tissue). Bars grouped under the same letters indicate no significant differences between mean values, whereas bars under different letters indicate significant differences as detected by SNK post hoc contrasts. Grey bars represent measurements of constructed oyster reefs, black bar represents a natural reef closed to harvest

Density of live oysters ( $>25 \mathrm{~mm}$ ) differed among the 8 sanctuaries included in the analyses $\left(F_{7,81}=8.85, \mathrm{p}<\right.$ $0.001)$, but not by sampling date $\left(F_{1,81}=2.31, \mathrm{p}=0.132\right)$ nor due to the interaction between date and sanctuary $\left(F_{7,81}=1.35, \mathrm{p}=0.223\right)$. Oyster density in the intertidal sanctuaries, Middle Marsh I and II and Bird Shoals, averaged 225 oysters $\mathrm{m}^{-2}$ across the $2 \mathrm{yr}$ and was higher than densities in all subtidal sanctuaries (Fig. 2; $\mathrm{p}<0.05$ for all SNK post hoc contrasts between Middle Marsh I and II and Bird Shoals versus each subtidal sanctuary). The lowest average oyster density, $0.25 \mathrm{~m}^{-2}$, was found at the Neuse River deep sanctuary (SNK post hoc contrast, $\mathrm{p}<0.05$ for Neuse River Deep versus all other sanctuaries).

The density of market-sized oysters and oyster biomass showed a pattern similar but not identical to that of total oysters. The density of market-sized oysters also varied by sanctuary $\left(F_{7,81}=5.05, \mathrm{p}<0.001\right)$, but not by collection year $\left(F_{1,81}=0.71, \mathrm{p}=0.400\right)$ or the interaction $\left(F_{7,81}=0.373, \mathrm{p}=0.914\right)$. Post hoc comparisons demonstrated that the average density of marketsized oysters was higher in the 3 intertidal sanctuaries than in all subtidal sanctuaries (Fig. 2). Among the subtidal sanctuaries, the density of market-sized oysters in the Neuse River shallow sanctuary was higher than the Wanchese, Deep Bay, and Neuse River deep sanctuaries, but similar to West Bay, which fell between and was indistinguishable from the Neuse River shallow and the remaining 3 subtidal sanctuaries. Oyster biomass varied by sanctuary $\left(F_{7,81}=5.65\right.$, $\mathrm{p}<0.001)$, but not by collection year $\left(F_{1,81}=0.21, \mathrm{p}=\right.$ $0.65)$ or the interaction $\left(F_{7,81}=1.48, \mathrm{p}=0.189\right)$. Post hoc comparisons of the sanctuary effect revealed 2 groupings of sanctuaries, with the 3 intertidal (Bird Shoals, Middle Marsh I and II) together with the subtidal Neuse River shallow sanctuaries having higher biomass than the Wanchese, Deep Bay, and Neuse River deep sanctuaries (Fig. 2). The West Bay sanctuary was intermediate and did not differ from either group.

Prevalence of Perkinsus marinus infection differed among sanctuaries $\left(F_{6,76}=120.3, \mathrm{p}<0.001\right)$ and collection year $\left(F_{1,76}=45.6, \mathrm{p}<0.001\right)$ with a significant sanctuary-collection year interaction $\left(F_{6,76}=15.1, \mathrm{p}<\right.$ 0.001). To examine the sanctuary-collection year interaction, we performed post hoc contrasts among sanctuaries within each collection year and between years within each sanctuary (Fig. 3). For 2002, the highest prevalence (50 to $80 \%$ ) occurred at oyster reefs within the Wanchese, West Bay, and Neuse River shallow sanctuaries (Fig. 3). Disease prevalence was lowest in Bird Shoals and Middle Marsh II (10 to 12\%), with Deep Bay and Middle Marsh I sanctuaries intermediate $(30 \%)$ and significantly different from both other groupings in 2002. In 2003, oysters within the West Bay sanctuary showed high disease prevalence levels $(60 \%)$. All other sanctuaries had relatively low prevalence (0 to $22 \%$ ) and did not differ among one another. For 5 sanctuaries, disease prevalence differed between years, in each case lower in 2003 (Fig. 3).

\section{Contrasts of reef crest versus base}

Significant differences between crest and base locations on sanctuary and open reefs were evident in the paired comparisons for oyster density, density of market-sized oysters, oyster biomass, average SH of oysters, and disease prevalence (Fig. 4). Mean oyster densities at crests were nearly twice as high as densities at the base (141 versus 78 oysters $\mathrm{m}^{-2}$, Fig. 4 ). The density of market-sized oysters and oyster biomass was $75 \%$ 


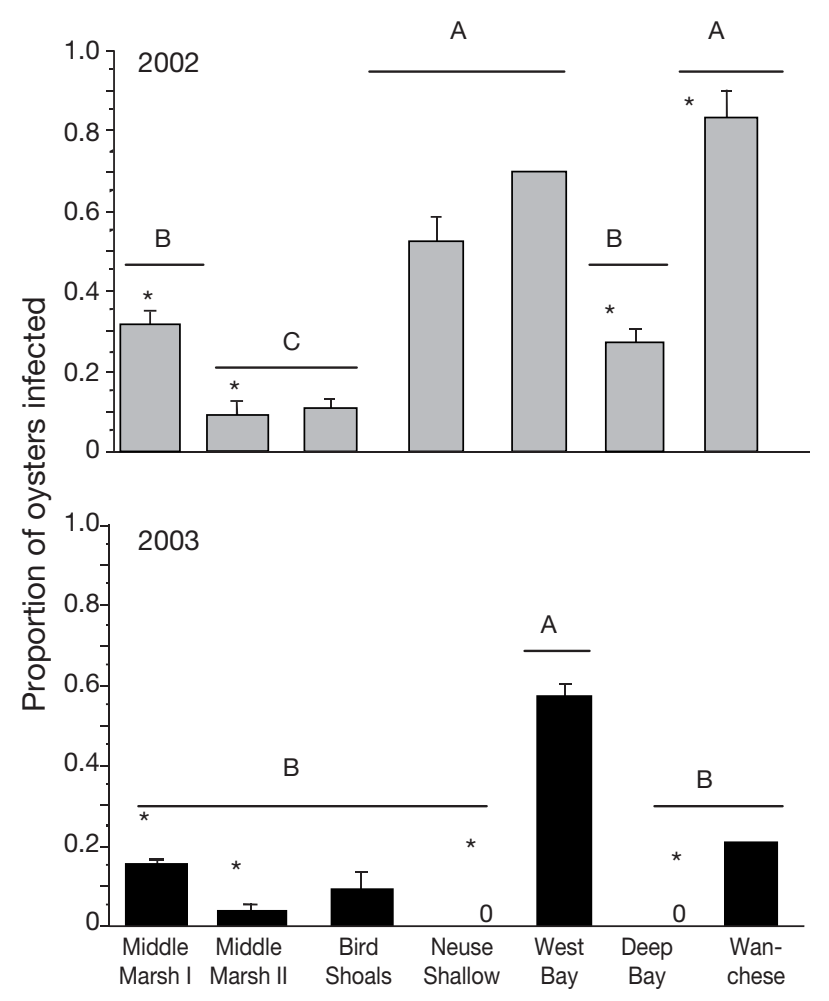

Fig. 3. Mean (+ $1 \mathrm{SE}$ ) prevalence of dermo infection in oysters from 7 North Carolina oyster sanctuaries in 2002 and 2003. The Neuse River deep sanctuary had no adult oysters present and was not included in the analysis. Bars grouped under the same letters indicate no significant differences between mean values, whereas bars under different letters indicate significant differences as detected by SNK post hoc contrasts. Asterisks indicate a significant difference between 2002 and 2003 for the sanctuary

higher at the crest than the base of the reef. Although not significant in the paired comparisons $(p=0.18)$, a trend existed of higher spat recruitment at crests of reefs than at their base (19 versus 14 oyster spat $\mathrm{m}^{-2}$ ). Prevalence of oysters infected by Perkinsus marinus was higher at the bases of reefs than on crests $(26 \%$ versus $22 \%$ ). However, the severity of infection in those oysters infected was similar, averaging 1.5 (on a scale of 0 to 5) for both crest and base positions.

\section{DISCUSSION}

Our surveys demonstrated that most oyster reefs within North Carolina no-harvest sanctuaries were successful (Table 2). By applying the minimal criteria of presence of vertical structure, live oysters, and evidence of successful recruitment in 1 of $2 \mathrm{yr}, 7$ sanctuaries could be judged successful, while 4 contained only failed reefs. From an oyster fishery perspective, examining the densities of market-sized oysters would be
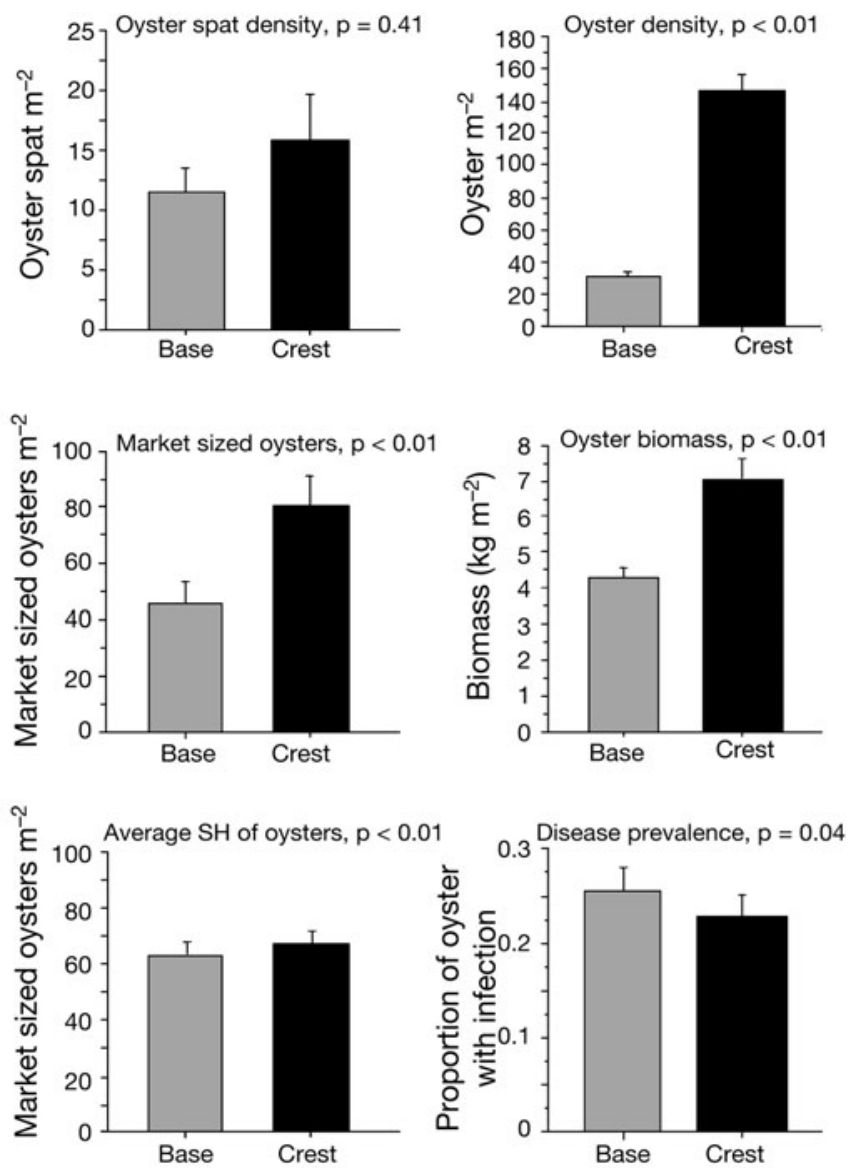

Fig. 4. Paired comparisons between selected variables measured at the base and crest of oyster reefs. All values represent the mean $+1 \mathrm{SD}$. P-values for paired $t$-tests are presented above each graph

the best indication of success. Densities of marketsized oysters ranged from 0 to $142 \mathrm{~m}^{-2}$ with only 4 sanctuaries having densities of market-sized oysters $>25 \mathrm{~m}^{-2}$ (Table 2). Although it is difficult to quantify the minimum density at which fishermen would abandon a reef for harvest, this density probably represents the low point of what they would consider harvestable. In contrast to the fishery perspective, some level of ecological success could be argued for all reefs that met the 3 minimal criteria and possibly for additional sanctuaries that did not. Ecological success does not require market-sized oysters in commercially profitable quantities. As long as oysters recruit regularly, low abundance of large oysters of market size does not preclude a restored oyster reef from sustaining valuable ecosystem services, which include enhancement of other fisheries for fish, crabs, and shrimps (Coen et al. 1999, Lenihan et al. 2001, Grabowski et al. 2005). Further, for the 2 sanctuaries that were classified as failures but which still had complex vertical structure (Crab Hole and Neuse River deep), these reefs may 
Table 2. Success of North Carolina oyster reef sanctuaries as judged by the minimum criteria (vertical structure, live oysters, and 1 yr successful recruitment) and mean density of all oysters $>25 \mathrm{~mm}$ shell height (SH), oyster biomass, and market-sized oysters (>75 $\mathrm{mm} \mathrm{SH})$

\begin{tabular}{|c|c|c|c|c|c|c|}
\hline \multirow{2}{*}{ Sanctuary } & \multirow{2}{*}{$\begin{array}{l}\text { Successful } \\
\text { reefs }\end{array}$} & \multicolumn{2}{|c|}{ Minimal } & \multirow{2}{*}{$\begin{array}{c}\text { Mean oyster } \\
\text { density } \\
\left(\text { no. } \mathrm{m}^{-2}\right)\end{array}$} & \multirow{2}{*}{$\begin{array}{c}\text { Mean oyster } \\
\text { biomass } \\
\left(\mathrm{kg} \mathrm{m}^{-2}\right)\end{array}$} & \multirow{2}{*}{$\begin{array}{l}\text { Mean market- } \\
\text { size oysters } \\
\left(\text { no. } \mathrm{m}^{-2}\right)\end{array}$} \\
\hline & & $\begin{array}{c}\text { Failed } \\
\text { reefs }\end{array}$ & $\begin{array}{c}\text { Overall } \\
\text { sanctuary }\end{array}$ & & & \\
\hline \multicolumn{7}{|l|}{ Intertidal } \\
\hline Bird Shoals & 6 & 0 & Success & 210 & 7.2 & 142 \\
\hline Middle Marsh I & 12 & 0 & Success & 205 & 9.6 & 105 \\
\hline Middle Marsh II & 11 & 0 & Success & 227 & 9.8 & 108 \\
\hline \multicolumn{7}{|l|}{ Subtidal } \\
\hline Bogue & 0 & 1 & Failure & 0 & 0 & 0 \\
\hline Neuse River shallow & 14 & 10 & Success & 95 & 6.9 & 46 \\
\hline Neuse River mid-depth & 0 & 12 & Failure & 0 & 0 & 0 \\
\hline Neuse River deep & 9 & 15 & Failure & 0.25 & 0 & 0 \\
\hline West Bay & 1 & 0 & Success & 92 & 3.1 & 24 \\
\hline Deep Bay & 1 & 0 & Success & 27 & 0.8 & 9 \\
\hline Crab Hole & 0 & 1 & Failure & 0 & 0 & 0 \\
\hline Wanchese & 1 & 0 & Success & 23 & 1.2 & 11 \\
\hline Total \% & $\begin{array}{c}60 \% \\
\text { success }\end{array}$ & $\begin{array}{c}40 \% \\
\text { failure }\end{array}$ & $\begin{array}{c}64 \% \\
\text { success }\end{array}$ & & & \\
\hline
\end{tabular}

serve as habitat for other sessile invertebrates and fishes, fulfilling at least 1 ecological service (Coen et al. 2007, Grabowski \& Peterson 2007).

Of the 3 intertidal sanctuaries containing restored reefs, all would be considered successful from an ecological or oyster fishery perspective, whereas success of restoration of subtidal reefs varied. All 3 intertidal areas had high densities of oysters including marketsized oysters. Intertidal restoration of oyster reefs may enjoy greater success in part because of relative ease of enforcement of prohibitions on use of bottom-disturbing fishing gear. Mobile fishing gear that penetrates into the bottom, like an oyster dredge or even a rake, carries the most serious risk of impact on benthic communities (Collie et al. 2000), degrades oyster reef habitat, and reduces oyster densities dramatically (Rothschild et al. 1994, Lenihan \& Peterson 1998, Lenihan \& Micheli 2000). The high structural relief and the abundant large oysters in the natural oyster reefs at Bird Shoals, an intertidal sanctuary where shellfishing has been prohibited for at least $30 \mathrm{yr}$, contrasts dramatically with fished intertidal reefs, which are seriously degraded (Lenihan \& Micheli 2000). We observed no rake tracks indicative of illegal shellfishing at Bird Shoals or any of the other 3 intertidal reef sanctuaries.

In contrast to the high success of the 3 intertidal oyster reefs, the 8 subtidal sanctuaries (Table 2) were variable in oyster density and biomass. Peterson \& Lipcius (2003) and Luckenbach et al. (2005) have suggested that oyster production or oyster density can be used as a measure of ecosystem services. As oyster density increases, bio-filtration, habitat complexity, provision of refuge, and forage species should increase. Under this metric, many of our subtidal oyster reefs still provide valuable ecosystem services, although density of market-sized oysters is low. At our subtidal reef sanctuaries, scattered tracks from dredge passage and gouges from tongs were evident. The loss of several restored subtidal oyster reefs, especially those missing in shallow and deep depths in the Neuse River estuary, can be attributed to illegal oyster fishing in those instances where we found only scattered shell debris over the site where a reef once stood.

Some environments may be intrinsically unsuitable for sustaining oyster reefs because of physical, chemical, or biological inhibitions to success. Improved capability to predict conditions leading to failure is likely to improve restoration success. We observed complete loss of all replicate reefs in 2 sanctuaries where the environment was apparently too energetic, as reflected in evidence of sand transport and total burial of the reef matrix. These failures at mid-depth in the Neuse River and in Bogue Sound could realistically be avoided by better a priori appreciation of prevailing physical processes, as indicated by coarse sand substrate. In our study, all such failures by burial occurred in subtidal habitats. High wave activity and sand transport are likely to render many intertidal sandflats physically unsuitable for oyster reef restoration, but such environments were not included in our study. One could also imagine extensive reef damage, even in typically quiescent intertidal areas, from hurricanes or other intense storms. Unlike persistent sedimentation, rapid recovery can follow intense storm damage to intertidal oyster reefs produced by exceptionally high oyster recruitment (Livingston et al. 1999). 
The dominant chemical limitation to oyster recovery and restoration is a complex of factors induced or intensified by eutrophication of the estuaries. With added nutrient loading, resultant phytoplankton blooms lead to extensive bottom-water hypoxia and generation of hydrogen sulfide, which if sustained for several days causes mass mortality of oysters and other sessile invertebrates (Lenihan \& Peterson 1998). This process primarily affects deeper areas (oysters at depths $>4.5 \mathrm{~m}$ ) in the Neuse River estuary, because sustained hypoxia is associated with density stratification of the water column, which inhibits mixing of oxygen from the surface waters. The failure of at least some Neuse River deep reefs, all of which were built in about $6 \mathrm{~m}$ of water (crest of reefs originally at $4 \mathrm{~m}$, high relief, or $5 \mathrm{~m}$, low relief), to persist was likely related to the joint impacts of hypoxia and hydrogen sulfide, which now frequently develop at that depth (Lenihan \& Peterson 1998, Lenihan et al. 2001). Only by constructing tall reefs and protecting them from damage by fishing gear so as to ensure their projection upwards into surface mixed layers can restored oyster reefs succeed in waters deeper than about $4.5 \mathrm{~m}$ in most estuaries.

One reef sanctuary in our study, Crab Hole, failed to harbor any live oysters, probably because of biological inhibitions. The large sanctuary reef at this site in eastern Pamlico Sound near the Outer Banks was structurally intact but completely covered by tunicates and other 'fouling' organisms in both survey years. Such fouling doubtless pre-empts space and inhibits oyster settlement, but may not be the cause of the absence of oysters. This northern portion of Pamlico Sound possesses low spawning stocks of oysters, such that low settlement and recruitment of oysters may limit successful restoration (Ortega \& Sutherland 1992). With oysters now so depleted in most estuaries of the Atlantic coast of the US (Kirby 2004), restoration strategies must be based on knowledge of hydrodynamics so as to concentrate reef restoration in areas of larval retention and seeded by sufficient spawning stock biomass to ensure sustained recruitment (Lipcius et al. 2008). For North Carolina's Pamlico Sound and the Maryland portion of Chesapeake Bay, spatial strategies of rebuilding of oyster stocks are necessary, first establishing core retention areas of high spawning stock biomass and then subsequently extending oyster reef restoration farther from the margins of successfully restored areas.

The biological limitation that is widely believed to represent the most serious impediment to recovery of native oysters in the Atlantic estuaries of the U.S. is the protozoan oyster disease Perkinsus marinus or dermo (Burreson \& Calvo 1996, Powell et al. 2008). Because oyster reef sanctuaries, like marine reserves more broadly (Agardy 1994, Allison et al. 1998), are inten- ded to allow build-up of locally high densities and enhance longevity in targeted populations, disease prevalence and severity may be expected to increase in sanctuaries. On the other hand, the protection from fishing disturbance and the resulting cultivation of high-relief structural habitat may enhance the resistance of oysters to infection given that the effects of disease on marine populations are typically greatest when combined with other physiological and environmental stressors (Anderson \& May 1979, Sousa \& Gleason 1989, Lenihan et al. 1999, Bruno et al. 2003). Over many generations, protecting populations from harvest may allow for natural selection of genotypes that are more resistant to dermo and other diseases (Burreson et al. 2000). Our survey revealed relatively low incidence and severity of dermo on reefs in sanctuaries. Although the size and density of oysters were greater on reef crests, oyster disease was less widespread in that more favorable (Lenihan 1999) environment. Our confirmation of previous results in Lenihan et al. (1999) and our failure to show high levels of disease prevalence or severity among large dense oysters on successful sanctuary reefs contradicts the prevailing dogma that the only means of combating dermo is to harvest oysters as quickly as possible after they reach marketable size before disease claims them (Andrews \& Ray 1989). Our data imply that by sustaining the high relief on sanctuary reefs by prohibiting fishing (Krantz \& Jordan 1996, Lenihan \& Peterson 1998) or by preventing gear damage to the reef habitat by gear restrictions (Lenihan \& Peterson 2004), oyster disease may not represent as serious an impediment to restoration and even to oyster fisheries as is currently believed (Krantz \& Jordan 1996).

Our survey of oyster reef sanctuaries that have remained protected from fishing for 3 to $30 \mathrm{yr}$ provides compelling evidence that restoration of the native eastern oyster is feasible. Perhaps the most encouraging sanctuary in our study was the set of Neuse River shallow reefs. Sampling of this sanctuary demonstrated that $10 \mathrm{yr}$ after restoration of its reefs, oyster densities and recruitment levels met not only criteria for ecological success but also those for fishery success. This success was achieved in a subtidal environment where restoration generally proved more difficult, reinforcing similar demonstrations of restoration success in intertidal reefs of Chesapeake Bay (O'Beirn et al. 1999). Pronouncing restoration of the native oyster unachievable is at least premature if not incorrect. The basis for this judgment has been a definition of success that includes only parameters relevant to recovery of the oyster fishery. Application of a broader definition of success that acknowledges the ecosystem services of oysters and the reefs they support would lead to many more conclusions of success. The widely publicized 
pronouncement that native oyster restoration is a failure has led to advocacy and state government support of a proposal to introduce an Asian oyster, Crassostrea ariakensis, into Chesapeake Bay to replace the native eastern oyster (NRC 2003, Zhou \& Allen 2003, Grabowski et al. 2004). Our results of the first comprehensive survey of decade-scale oyster success in protected sanctuaries provides hope and incentive for patience and a more interdisciplinary ecosystem-based approach to oyster reef restoration.

Acknowledgements. Much of the initial and follow-up research for this project was performed while each of the authors was at the Institute of Marine Sciences, University of North Carolina at Chapel Hill. We thank the staff for all their support. We are grateful to C. Hardy and M. Marshall, North Carolina Division of Marine Fisheries, for their assistance in locating reefs and analysis of disease samples. D. Gaskill, T. Ellis, and G. Safrit performed much of the field work and disease analyses. Funding for this project was provided through a grant from the National Sea Grant's Oyster Disease Research Program (C.H.P. and S.P.P.). Finally, we thank R. Lipcius and 3 anonymous referees for comments that improved the manuscript.

\section{LITERATURE CITED}

Agardy MT (1994) Advances in marine conservation: the role of marine protected areas. Trends Ecol Evol 9:267-270

Allison G, Lubchenco J, Carr M (1998) Marine reserves are necessary but not sufficient for marine conservation. Ecol Appl 8:S79-S92

Anderson RM, May R (1979) Population dynamics of infectious disease. Nature 280:361-367

Andrews JD (1988) Epizootiology of the disease caused by the oyster pathogen Perkinsus marinus and its effects on the oyster industry. Am Fish Soc Spec Publ 18:47-63

Andrews JD, Ray SM (1989) Management strategies to control the disease caused by Perkinsus marinus. Am Fish Soc Spec Publ 18:257-264

Breitburg DL, Coen LD, Luckenbach MW, Mann R, Posey M, Wesson JA (2000) Oyster reef restoration: convergence of harvest and conservation strategies. J Shellfish Res 19: 371-377

Bruno JF, Petes LE, Harvell CD, Hettinger A (2003) Nutrient enrichment can increase the severity of coral diseases. Ecol Lett 6:1056-1061

Burreson EM, Calvo LMR (1996) Epizootiology of Perkinsus marinus disease of oysters in Chesapeake Bay, with emphasis on data since 1985. J Shellfish Res 15:17-34

Burreson E, Gross G, Kennedy V, Luckenbach M and others (2000) Chesapeake Bay oyster restoration. Consensus of a meeting of scientific experts. Chesapeake Research Consortium, VIMS, Gloucester Point, VA

Carlton JT (1989) Man's role in changing the face of the ocean: biological invasions and implications for conservation of near-shore environments. Conserv Biol 3:265-273

Coen LD, Luckenbach MW (2000) Developing success criteria and goals for evaluating oyster reef restoration: ecological functioning or resource exploitation? Ecol Eng 15:323-343

Coen LD, Luckenbach MW, Breitburg DL (1999) The role of oyster reefs as essential fish habitat: a review of current knowledge and some new perspectives. In: Benaka LR (ed) Fish habitat: essential fish habitat and restoration. Am Fish Soc Symp 22:438-454

Coen LD, Brumbaugh RD, Bushek D, Grizzle R and others (2007) Ecosystem services related to oyster restoration. Mar Ecol Prog Ser 341:303-307

Collie JS, Hall SJ, Kaiser MJ, Poiner IR (2000) A quantitative assessment of fishing impacts on shelf-sea benthos. J Anim Ecol 69:785-798

Dame RF, Zingmark RG, Haskin E (1984) Oyster reefs as processors of estuarine materials. J Exp Mar Biol Ecol 83: 239-247

> DeAlteris JT (1988) The geomorphic development of Wreck Shoal, a subtidal oyster reef of the James River. Estuaries 11:240-249

Grabowski JH, Peterson CH (2007) Restoring oyster reefs to recover ecosystem services. In: Cuddington $\mathrm{K}$, Byers JE, Wilson WG, Hastings A (eds) Ecosystem engineers: concepts, theory and applications. Elsevier-Academic Press, Amsterdam, p 281-298

Grabowski JH, Peterson CH, Powers SP, Gaskill D, Summerson HC (2004) Growth and survivorship of non-native (Crassostrea gigas and Crassostrea ariakensis) versus native eastern oysters (Crassostrea virginica). J Shellfish Res 23:781-793

Grabowski JH, Hughes AR, Kimbro DL, Dolan MA (2005) How habitat setting influences restored oyster reef communities. Ecology 86:1926-1935

Hargis WJ Jr, Haven DS (1988) The imperiled oyster industry of Virginia: a critical analysis with recommendations for restoration. Virginia Sea Grant Marine Advisory Service Special Report

Jackson JBC, Kirby MX, Berger WH, Bjorndal KA and others (2001) Historical overfishing and the recent collapse of coastal ecosystems. Science 293:629-638

Kirby MX (2004) Fishing down the coast: historical expansion and collapse of oyster fisheries along the continental margins. Proc Natl Acad Sci USA 101:13096-13099

> Kneib RT (2003) Bioenergetic and landscape considerations for scaling expectations of nekton production from intertidal marshes. Mar Ecol Prog Ser 264:279-296

Krantz GE, Jordan SJ (1996) Management alternatives for protecting Crassostrea virginica fisheries in Perkinsus marinus enzootic and epizootic areas. J Shellfish Res 15:167-176

Lenihan HS (1999) Physical-biological coupling on oyster reefs: how habitat structure influences individual performance. Ecol Monogr 69:251-275

Lenihan HS, Micheli F (2000) Biological effects of shellfish harvesting on oyster reefs: resolving a fishery conflict using ecological experimentation. Fish Bull (Wash DC) 98:86-95

> Lenihan HS, Peterson CH (1998) How habitat degradation through fishery disturbance enhances impacts of hypoxia on oyster reefs. Ecol Appl 8:128-140

Lenihan HS, Peterson CH (2004) Conserving oyster reef habitat by switching from dredging and tonging to diverharvesting. Fish Bull (Wash DC) 102:298-305

Lenihan HS, Micheli F, Shelton SW, Peterson CH (1999) The influence of multiple environmental stressors on susceptibility to parasites: an experimental determination with oysters. Limnol Oceanogr 44:910-924

Lenihan HS, Peterson CH, Byers JE, Grabowski JH, Thayer GW, Colby D (2001) Cascading of habitat degradation: oyster reefs invaded by refugee fishes escaping stress. Ecol Appl 11:764-782

> Lipcius RN, Eggleston DB, Shreiber S, Seitz RD and others (2008) Importance of metapopulation connectivity to restocking and restoration of marine species. Rev Fish Sci 16:101-110 
Livingston RJ, Howell RL, Niu XF, Lewis FG, Woodsum GG (1999) Recovery of oyster reefs (Crassostrea virginica) in a Gulf estuary following disturbance by two hurricanes. Bull Mar Sci 64:465-483

Luckenbach MW, Coen LD, Ross PG, Stephen JA (2005) Oyster reef habitat restoration: relationships between oyster abundance and community development based on two studies in Virginia and South Carolina. J Coast Res 40: $64-78$

Mann R (2000) Restoring oyster reef communities in the Chesapeake Bay: a commentary. J Shellfish Res 19: 335-340

Mann R, Powell EN (2007) Why oyster restoration goals in the Chesapeake Bay are not and probably cannot be achieved. J Shellfish Res 26:905-917

> Naylor R, Williams SL, Strong DR (2001) Aquaculture: a gateway for exotic species. Science 294:1655-1656

Nelson KA, Leonard LA, Posey MH, Alphin TD, Mallin MA (2004) Using transplanted oyster beds to improve water quality in small tidal creeks: a pilot study. J Exp Mar Biol Ecol 298:347-368

Newell RIE, Cornwell JC, Owens MS (2002) Influence of simulated bivalve biodeposition and microphytobenthos on sediment nitrogen dynamics: a laboratory study. Limnol Oceanogr 47:1367-1379

NRC (National Research Council) (2003) Non-native oysters in the Chesapeake Bay. National Academy Press, Washington, DC

O'Beirn FX, Luckenbach MW, Mann R, Harding J, Nesterode $\mathrm{J}$ (1999) Ecological functions of constructed oyster reefs along an environmental gradient in Chesapeake Bay. Final Report, Aquatic Reef Habitat Program, Chesapeake Bay Program, Anapolis, MD

Ortega S, Sutherland JP (1992) Recruitment and growth of the eastern oyster, Crassostrea virginica, in North Carolina. Estuaries 15:158-170

Paynter KT, Burreson EM (1991) Effects of Perkinsus marinus infection in the eastern oyster, Crassostrea virginica: 2. Disease development and the impact on growth rate at different salinities. J Shellfish Res 10:425-431

Peterson CH, Lipcius RN (2003) Conceptual progress towards predicting quantitative ecosystem benefits of ecological

Editorial responsibility: Romuald Lipcius,

Gloucester Point, Virginia, USA restorations. Mar Ecol Prog Ser 264:297-307

$>$ Peterson CH, Grabowski JH, Powers SP (2003) Estimated enhancement of fish production resulting from restoring oyster reef habitat: quantitative valuation. Mar Ecol Prog Ser 264:251-266

Pomeroy LR, D'Elia CF, Shaffner LC (2006) Limits to top-down control of phytoplankton by oysters in Chesapeake Bay. Mar Ecol Prog Ser 325:301-309

Posey MH, Alphin TD, Powell CM, Townsend E (1999) Oyster reefs as habitat for epibenthic fish and decapods. In: Luckenbach M, Mann R, Wesson J (eds) Oyster reef habitat restoration: a synopsis of approaches. Virginia Institute of Marine Science Press, Williamsburg, VA, p 229-237

Powell EN, Ashton-Alcox KA, Kraueter JN, Ford SE, Bushek D (2008) Long-term trends in the oyster population dynamics in Delaware Bay: regime shifts and response to disease. J Shellfish Res 27:729-755

Powers SP, Peterson CH, Christian RR, Sullivan E, Powers MJ, Bishop M, Buzzelli CP (2005) Effects of eutrophication on bottom habitat and prey resources of demersal fishes. Mar Ecol Prog Ser 302:233-243

Quick JA Jr, Mackin JG (1971) Oyster parasitism by L. marina in Florida. Florida Department of Natural Resources, Mar Res Lab Prof Pap Ser 13

Ray SM (1963) A review of the culture method for detecting D. marinum, with suggested modifications and precautions. Proc Natl Shellfish Assoc 54:389-404

Rothschild BJ, Ault JS, Goulletquer P, Héral M (1994) Decline of the Chesapeake Bay oyster population: a century of habitat destruction and overfishing. Mar Ecol Prog Ser 111:29-39

Soniat TM (1996) Epizootiology of Perkinsus marinus disease of Eastern oysters in the Gulf of Mexico. J Shellfish Res 15:35-43

Sousa WP, Gleason M (1989) Does parasitic infection compromise host survival under extreme environmental conditions? The case of Cerithidea californica (Gastropoda: Prosobranchia). Oecologia 80:456-464

- Wells HT (1961) The fauna of oyster beds, with special reference to the salinity factor. Ecol Monogr 31:239-266

Zhou M, Allen SK (2003) A review of published work on Crassostrea ariakensis. J Shellfish Res 22:1-20

Submitted: May 5, 2008; Accepted: April 29, 2009

Proofs received from author(s): August 21, 2009 